\title{
Territoriality Beyond the State: The EU's Territorial Claims and the Search for Their Legitimacy
}

\author{
Josef Weinzierl*(i) \\ Faculty of Law, University of Oxford, Oxford, England \\ ${ }^{\star}$ Corresponding author: josef.weinzierl@law.ox.ac.uk
}

(Received 30 July 2020; accepted 19 October 2020)

\begin{abstract}
Quite a few recent ECJ judgments touch on various elements of territorial rule. Thereby, they raise the profile of the main question this Article asks: Which territorial claims does the EU make? To provide an answer, the present Article discusses and categorizes the individual elements of territoriality in the EU's architecture. The influence of EU law on national territorial rule on the one hand and the emergence of territorial governance elements at the European level on the other provide the main pillars of the inquiry. Once combined, these features not only help to improve our understanding of the EU's distinctly supranational conception of territoriality. What is more, the discussion raises several important legitimacy questions. As a consequence, the Article calls for the development of a theoretical model to evaluate and justify territoriality in a political community beyond the state.
\end{abstract}

Keywords: Territoriality; European borders; jurisdiction; legitimate authority; demoicracy

\section{A. Introduction}

Desperate refugees sailing towards the old continent serve as a sad reminder of the salience of being inside or outside the EU, and of the moral judgment involved in including and excluding. ${ }^{1}$ Even more topical, the COVID-19 pandemic has led to the temporary closure of many intra-EU borders, while export restrictions on vaccines show the importance of the EU's external borders. These observations illustrate the broader theme of the present Article, which traces the development of a supranational conception of territorial rule. The crucial question is how geographical space relates to normative rule in the EU. Quite a few recent ECJ judgments touch on territorial aspects of EU rule, such as EU law's relationship to border disputes between Member States, ${ }^{2}$ the reach of territorial sovereignty and public order as a defense against EU law obligations, ${ }^{3}$ how the territorial extension of EU law to EFTA-States affects the extradition regime under the European Arrest Warrant, ${ }^{4}$ and how EU law protects EU citizens' personal data in case private companies

The author would like to thank Pavlos Eleftheriadis, Francesca Episcopo, and Amédéé von Moltke for valuable comments on earlier drafts.

${ }^{1}$ See generally Matthew Carr, Fortress Europe: Dispatches from a Gated Continent (2012).

${ }^{2}$ See ECJ, Case C-457/18, Slovenia v. Croatia, ECLI:EU:C:2020:65 (Jan. 31, 2020), https://curia.europa.eu/juris/liste.jsf? num $=\mathrm{C}-457 / 18$.

${ }^{3}$ See ECJ, Case C-715/17, Comm'n v. Poland, ECLI:EU:C:2020:257 (Apr. 2, 2020), https://curia.europa.eu/juris/liste.jsf? num $=\mathrm{C}-715 / 17$.

${ }^{4}$ See ECJ, Case C-897/19, Ruska Federacija v. I.N., ECLI:EU:C:2020:262 (Apr. 2, 2020), https://curia.europa.eu/juris/liste.jsf? num $=\mathrm{C}-897 / 19$.

(C) The Author(s) 2021. Published by Cambridge University Press on behalf of the German Law Journal. This is an Open Access article, distributed under the terms of the Creative Commons Attribution licence (http://creativecommons.org/licenses/by/4.0/), which permits unrestricted re-use, distribution, and reproduction in any medium, provided the original work is properly cited. 
transfer it to third countries. ${ }^{5}$ In light of these scattered manifestations of territorial elements in the EU's authority claim, I use insights from EU law, political theory, and political geography to shed light on the EU's territorial claims. These insights help us understand better how the EU governs. More importantly, the EU's territorial claims raise various legitimacy challenges that call for developing a proper theoretical framework.

This Article proceeds as follows. Section B highlights the importance of territoriality for the exercise of political authority and explains why state territoriality does not conceptually exhaust the notion of territorial rule. Thereafter, Section $\mathrm{C}$ will primarily focus on how EU law affects the territorial rule of Member States before paying more attention to the development of territorial elements on the supranational level in Section D. Section E will review the role of EU citizens, and Section F will discuss various functional elements in the evolving picture of the EU's conception of territoriality, followed by a summary in Section G. Finally, Section H concludes that the EU's territorial claims call for developing a proper theoretical framework in order to evaluate their legitimacy.

\section{B. The Conceptual Space for Territoriality Beyond the State}

A fundamental distinction between territorial and functional rule frequently reflects the underlying duality of statist and international governance models. In essence, bounded territorial rule represents the post-Westphalian domain of states. ${ }^{6}$ Limited functional governance, by contrast, characterizes traditional international organizations. To locate the EU on this spectrum, I want to begin by liberating the notion of territoriality itself from its statist straitjacket. That implies, first, that we know what state territoriality looks like.

The pedigree of internal and external state sovereignty is to claim and uphold ultimate authority over a given territory. These two dimensions characterize the state's internal superiority over other authorities and its efforts to shield its territory from external influence. This is how we understand territoriality, namely the characteristically strong relationship between people, place, and political institutions in states. Post-Westphalian sovereignty is necessarily and intrinsically spatial because the state's territory circumscribes the legitimate realm of its political power. To illustrate, in David Miller's conceptualization, states claim a tripartite form of territorial rights, namely the right to jurisdiction, the right to use the territory's resources, and the right to control borders. ${ }^{8}$ The conceptual link between states and territoriality seems so strong that an influential view in political theory views territory as the property of, or even identical to, the state. ${ }^{9}$ One can be forgiven, then, for assuming that the very idea of territorial rule is limited to nation states.

Yet, the paradigm behind territorial nation-statehood itself is historically contingent. Because territoriality represents a governance tool—serving to the end of governing discrete societies-it has always been open for various manifestations of territorial rule, for example in empires or federal systems. ${ }^{10}$ In his impressive study, The Birth of Territory, Stuart Elden traces the role of territoriality in conceptualizing political authority since the early days of the Greek polis.

\footnotetext{
${ }^{5}$ See ECJ, Case C-311/18, Data Prot. Comm'r v. Facebook Ireland Ltd. and Maximillian Schrems, ECLI:EU:C:2020:559 (July 16, 2020), https://curia.europa.eu/juris/liste.jsf?num=C-311/18.

${ }^{6}$ For a short overview, see Neil Walker, The Place of Territory in Citizenship, in THE Oxford HandBook OF CITIZENSHIP 562-64 (Ayelet Shachar et al. eds., 2017). Rarely, if ever, has this model coincided with reality. See William Walters, Europe's Borders, in The SAGE HandBook of European Studies 489-90 (Chris Rumford ed., 2009).

${ }^{7}$ See Kal Raustiala, The Geography of Justice, 73 FORDHAM L. REV. 2501, 2508-09 (2005).

${ }^{8}$ See David Miller, Territorial Rights: Concept and Justification, 60 POL. STUD. 252 (2012). For a comprehensive overview of a State's claims over territory, see A. John Simmons, Boundaries of Authority ch. 5 (2016).

${ }^{9}$ See Gianfranco Poggi, The State: Its Nature, Development and Prospects 22 (1990); Margaret Moore, A Political Theory of Territory ch. 2 (2015).

${ }^{10}$ See Moore, supra note 9, at 49; AnNa Stilz, Territorial Sovereignty: A Philosophical Exploration 2-6 (2019).
} 
He concludes that territoriality is highly contingent on the historical, geographic, and politicaleconomic background conditions. ${ }^{11}$ Therefore, it is hardly surprising that current developments, especially globalization, challenge the very idea of territoriality almost as much as they test state sovereignty itself. ${ }^{12}$ Thus, from a historical point of view, there is no reason to assume that only States may develop territorial rule.

Conceptually, moreover, state territorial rule does not exhaust the notion of territoriality, although states surely represent its strongest contemporary manifestation. Territoriality expresses a normative relationship between humans, a distinct patch of the earth, and how political institutions administer it. Territorial rule, or territoriality, articulates the idea of administering a bordered space. It represents a generic governance tool that links a geographic place, the people who live there, and the exercise of normative power. In short, territoriality is a function with three components: People, place, and power. The intention to exert normative control transforms a mere spatial area into an important component of political authority. ${ }^{13}$ One of the main elements of territorial rule is jurisdictional authority defined by geographical criteria, otherwise known as territorial jurisdiction. This notion implies that the mere fact that a measure has effects on a given territory suffices to trigger the application of a given legal order. While territorial jurisdiction is first and foremost a feature of state authority, we will see below how the ECJ and the EU legislator use a similar mechanism to trigger the application of EU law.

To summarize, there is room for territoriality in governing supra-state polities. Both historically and conceptually, the notion of territoriality permits a non-state polity, such as the EU, to develop its own notion of territorial rule. Territoriality helps to explain the various elements in the EU's authority claim, to which this Article turns to next. The main aim of the following reflections is to uncover the EU's conception of territoriality, understood as distinctly supranational relationship between place, people(s), and power. That is the necessary groundwork for evaluating the legitimacy of these territorial claims.

\section{The Reflexive Relationship Between EU Law and National Territory}

The starting point of this Article was a reflection on the link between State sovereignty and territoriality. Therefore, it seems only natural to begin the examination of the EU's territorial claims with a study of how it affects state territoriality. To put it broadly, how does the EU's geographical territory relate to the territory of the Member States? The idea of EU territory itself derives from and remains parasitic on national territory. Prominent features of the EU's governance have profound effects on core elements of the national territorial rule and transform the very idea of state territoriality. The relationship between national and European territorial rule is thus reflexive.

\section{The EU's "Parasitic" Territory}

Article 52 of the Treaty on European Union ("TEU”) and Article 355 of the Treaty on the Functioning of the European Union (“TFEU”) [hereinafter The Treaties], respectively, provide the natural starting point for trying to grasp the nature of the EU's territory. These provisions define the geographic space of the EU by listing the individual Member States' territories as well

\footnotetext{
${ }^{11}$ See Stuart Elden, The Birth of Territory (2013). For a critical historical account of the State-territory nexus, see Benno Teschke, The Metamorphoses of European Territoriality: A Historical Reconstruction, in State TerRITORIALITY AND EUROPEAN INTEGRATION (Michael Burgess \& Hans Vollaard eds., 2006).

${ }^{12}$ See Hannah L. Buxbaum, Territory, Territoriality, and the Resolution of Jurisdictional Conflict, 57 AM. J. COMPAR. L. 631, 631-35 (2009); Ralf Michaels, Territorial Jurisdiction After Territoriality, in Globalisation AND JuRISDICTION 105 (Pieter J. Slot \& M. K. Bulterman eds., 2004).

${ }^{13}$ See Robert D. Sack, Human Territoriality: A Theory, 73 Annals of the Ass'N Am. GeOgraphers 55 (1983); CATHRYN Costello, The Human Rights of Migrants and Refugees in European LaW 18 (2016); see also Charles S. Maier, Does Europe Need a Frontier?, in EUROPE UnbOUND: ENLARGING AND RESHAPING THE BOUNDARIES OF THE EUROPEAN UNION 20 21 (Jan Zielonka ed., 2003).
} 
as certain exceptions. ${ }^{14}$ Geographically, the sum is not more than its parts. The EU's territory is in principle coextensive with the combined territories of its Member States. Now, these lists per se hardly advance our understanding of the nature of the EU's territoriality. Recall that national constitutions occasionally refer to the territory of constituent sub-national component-entities, ${ }^{15}$ which, however, does not render their territory dependent on these lower levels. The Treaty definition nonetheless illustrates a sobering point of departure: The EU does not control its territory in a meaningful sense. Rather, the Member States control their respective territories and define their borders under international law. The EU's territory accordingly changes automatically in case of territorial changes on the national level. ${ }^{16}$ The accession of a new and the exit of a current Member State provide the most obvious examples in that regard. There are, however, more subtle manifestations of such changes. For example, when a Member State gains-German reunification —or loses control over territory-French de-colonialization of Algeria—or by agreeing to exempt certain national territories from treaty application as with Greenland in Article 204 TFEU. ${ }^{17}$ In short, EU territory is parasitic on national territory.

Not unlike a parasite's host, national-territorial rule as an element of State authority is profoundly affected by this connection. Recent case law shows that core elements of national-territorial ruleeven if protected in the EU Treaties - fail to fall outside the scope of EU law. More generally, the daily operation of the EU contributes to a remarkable de-territorialization of national rule.

\section{The Effect of EU Law on National Control Over Borders and Territories}

It is a truism of international law that states control their territories and borders. This central element of governing seems to be part of the state's job description-and the above explanation of the EU Treaties appears to support this. In the EU, this is nonetheless not the end of the story. Indeed, EU Member States continue to be responsible for their borders. In a complex border dispute between Croatia and Slovenia, the Court held that such matters remain in the hands of the Member States:

In the absence, in the Treaties, of a more precise definition of the territories falling within the sovereignty of the Member States, it is for each Member State to determine the extent and limits of its own territory, in accordance with the rules of public international law .... Moreover, Article 77(4) TFEU points out that the Member States have competence concerning the geographical demarcation of their borders, in accordance with international law. ${ }^{18}$

\footnotetext{
${ }^{14}$ The Treaties thus contain a lex specialis to Article 29 of the Vienna Convention on the Law of Treaties. For a discussion, see Christina Eckes \& Ramses Wessel, The European Union from an International Perspective: Sovereignty, Statehood, and Special Treatment, in 1 The Oxford Principles of European Union Law: The European Union Legal Order 33, 90 (Takis Tridimas \& Robert Schütze eds., 2017).

${ }^{15}$ See Luiza Bialasiewicz, Stuart Elden \& Joe Painter, The Constitution of EU Territory, 3 ComPar. Eur. Pol. 333, 339 (2005). For the role of Member State territory in the Treaties see Violeta Moreno-Lax \& Cathryn Costello, The Extraterritorial Application of the EU Charter of Fundamental Rights: From Territoriality to Facticity, the Effectiveness Model, in THE EU Charter of Fundamental Rights: A Commentary 1657, 1663 (Steve Peers et al. eds., 2014).

${ }^{16} \mathrm{See}$ ECJ, Case C-61/77, Comm'n v. Ireland, ECLI:EU:C:1978:29 (Feb. 16, 1978), paras. 46-51, https://curia.europa.eu/juris/ liste.jsf?num=C-61/77; ECJ, Case C-132/14, Parliament v. Council, ECLI:EU:C:2015:813 (Dec. 15, 2015), para. 77, https://curia. europa.eu/juris/liste.jsf?num=C-132/14. This territorial change reflects the international law rule of "moving treaty frontiers" (bewegliche Vertragsgrenzen) as evidenced in Article 15 of the Vienna Convention on Succession of States in Respect of Treaties.

${ }^{17}$ See Consolidated Version of the Treaty on the Functioning of the European Union art. 204, Oct. 26, 2012, 2012 O.J. (C 326) 47 [hereinafter TFEU] ("The provisions of Articles 198 to 203 shall apply to Greenland, subject to the specific provisions for Greenland set out in the Protocol on special arrangements for Greenland, annexed to the Treaties.”). Article 204 of the TFEU shows e contrario that the remaining primary law does not apply to Greenland; see also Jacques Ziller, Flexibility in the Geographical Scope of EU Law: Diversity and Differentiation in the Application of Substantive Law on Member States' Territories, in CONSTITUTIONAL CHANGE IN the EU: From Uniformity to FleXibility? 113, 118-20 (Graínne De Búrca \& Joanne Scott eds., 2000).

${ }^{18}$ Slovenia, Case C-457/18 at para. 106. See Luigi Lonardo, Republic of Slovenia v Republic of Croatia (C-457/18): "Am I my Brother's Keeper?" International Agreements by Member States and the Limits of the European Court of Justice's Jurisdiction, 46(1) EUR. L. REV. 105 (2021) (placing the judgment in the broader context of the ECJ's jurisdiction in relation to international law).
} 
The Treaty explicitly confirms that the geographical determination of national borders remains the competence of Member States. Article 77 (4) TFEU, quite paradoxically, upholds this national competence in a supranational treaty. ${ }^{19}$ Given that both Member States are subject to the duty of sincere cooperation towards each other, the EU, and other Member States, however, it is incumbent upon them to resolve the dispute swiftly and in accordance with international law. ${ }^{20}$ This provides a first impression of how the EU binds Member States to one another in a way that enables the EU to exert normative influence beyond the scope of its explicit competences, with distinct consequences for national territorial rule.

Beyond this rather narrow issue of locating and controlling borders, the Member States uphold public order and claim the monopoly of force as well as unlimited authority coextensive to their territories. ${ }^{21}$ Doing so characterizes them as sovereign states. ${ }^{22}$ Article 72 TFEU, and its jurisdictional equivalent, Article 276 TFEU, indeed underline the Member States' territorial claims by recognizing their "responsibility . . . with regard to the maintenance of law and order and the safeguarding of internal security." Similarly, Article 4 (2) TEU obligates the EU to respect the territorial integrity of its Member States. Thus, national territory does not disappear through the European transformation. To the contrary, it is explicitly protected in the treaties. Think of the recent extraordinary measures to combat the COVID-19 pandemic, such as the closure of intra-EU borders, as powerful reminders that national borders and national territories still exist and matter.

However, it does not follow that the way Member States govern their territory is an EU law-free zone. That is at least what the ECJ held when Eastern European Member States tried to justify their refusal to participate in an EU-wide refugee relocation scheme with recourse to Article 72 TFEU's public-order trias and Article 4 (2) TEU. The Court confirms that not even salient areas like the maintenance of law and order constitute a domaine réservé, which would jeopardize the binding nature and uniform application of EU law. ${ }^{23}$ In that case, the Member States in question failed to substantiate that the relocation of several refugees causes any palpable threat to their domestic public order and, consequently, could not invoke Article 72 TFEU as a defense.

This shows that the general divide between the EU's competencies, as enumerated in Article 2-6 TFEU, and its jurisdiction or the scope of European law that arises especially from the functional nature of fundamental freedoms and various legal bases in the Treaties, applies to territoriality as well. The scope of EU law considerably transcends the EU's explicit competences. Moreover, the Treaties explicitly mention the protection of such salient areas of state sovereignty has the counterintuitive effect of bringing the interpretation of these notions into the purview of EU law and of the ECJ. The combination of these two elements makes it the case that EU law claims a say in relation to significant territorial elements of its Member States' governance.

So far, the EU's territory's derivative and parasitic nature means that its geographic reach depends on and necessarily coincides with the Member States' combined territory. ${ }^{24}$ That, however, does not prevent EU law from affecting and shaping the territorial sovereignty of its Member

\footnotetext{
${ }^{19}$ See TFEU at art. 77(4) ("This Article shall not affect the competence of the Member States concerning the geographical demarcation of their borders, in accordance with international law.").

${ }^{20} I d$. at para. 109.

${ }^{21}$ See Maier, supra note 13 , at 22.

${ }^{22}$ For a remarkable supranational confirmation of their sovereignty, see ECJ, Case C-621/18, Andy Wightman and Others v. Sec'y of State for Exiting the E.U., ECLI:EU:C:2018:999 (Dec. 10, 2018), paras. 50, 56, https://curia.europa.eu/juris/liste.jsf? num $=\mathrm{C}-621 / 18$.

${ }^{23}$ See Comm'n, Case C-715/17 at para. 143.

${ }^{24}$ See Regulation 604/2013, of the European Parliament and of the Council of 26 June 2013 Establishing the Criteria and Mechanisms for Determining the Member State Responsible for Examining an Application for International Protection Lodged in One of the Member States by a Third-Country National or a Stateless Person, 2013 O.J. (L 180) 37, 40 (EC) (making the Member State of first entry responsible for the asylum application). Similarly, even Eurodac-the EU biometric system to monitor migration - relies on the national borders of Member States. See Walters, supra note 6, at 449; Virginie Mamadouh, The Territoriality of European Integration and the Territorial Features of the European Union: The First 50 Years, 92 Tijdschrift voor ECONOMISCHE EN Sociale Geografie 420, 427 (2001).
} 
States. Aside from the recent examples discussed above, namely borders and public order, the EU claims the authority to transform national-territorial rule through its daily operation. One of the most obvious effects of EU law is a regulatory de-territorialization from the perspective of nation States. Let us take a closer look.

\section{The De-Territorialization of National Rule}

The EU's legal and institutional architecture itself creates territorial cohesion in Europe. EU law's emphasis on coherence and uniformity naturally contributes to a common European space for business, people, and states. ${ }^{25}$ Primarily, the internal market paradigm is built upon the underlying intention to tear down any protectionist walls that unreasonably prohibit the interaction of goods and persons. Above all, the operation of the fundamental freedoms in their proactive interpretation by the ECJ has always spearheaded this development. Because the internal market is defined as an "area without internal frontiers" (Article 26 (2) TFEU), the Treaty foresees the tectonic changes it brings about for territorial rule. ${ }^{26}$

These territory-building economic elements bring to mind how a centrally organized capitalist economy contributed to the formation of the sovereign state in the late Middle Ages. ${ }^{27}$ And rightly so, for territoriality provides "the conceptual foundation of regulatory authority over transactions or conduct. Historically, in its strictest sense, the concept referred to the exclusive authority of a State to regulate events occurring within its borders." 28 The EU's way of governing creates a new, distinctly supranational kind of territoriality, that facilitates transactions across borders. In the spirit of the quote, the EU's regulatory authority over transactions reflexively creates a new form of territoriality. This by itself fosters internal coherence and-as a necessary consequence-external delimitation. It exposes businesses and citizens alike to alternative regulatory and cultural ways, creating pressure for change and assimilation. ${ }^{29}$ This feature significantly affects the national control of territory that the quote rightly cites as territoriality's historical origin. It leads to "territorial competition" 30 among the Member States, which may not reserve their resources for their own people and use borders as a hurdle for imported goods unless there are good reasons.

A few examples help to get a sense of how EU law affects national-territorial rule. Consider recent developments in EU private international law, where the relevant link to determine the applicable law shifts evermore from rigid national categories, such as citizenship, towards the more flexible "habitual residence" in a Member State. This loosens the jurisdictional ties to one's homeland in important areas such as inheritance. ${ }^{31}$

Moreover, the Area of Freedom, Security and Justice (AFSJ) demonstrates the implications of this in less economic terms. First, Member States may not refuse entry to EU citizens from other

\footnotetext{
${ }^{25}$ See Anand Menon \& Stephen Weatherill, Transnational Legitimacy in a Globalising World: How the European Union Rescues its States, 31 W. EUR. PoL. 397, 409 (2008) ("European market-building is reflected, not in European State-building, but in making national systems more European.").

${ }^{26} \mathrm{TFEU}$ at art. 26(2) ("The internal market shall comprise an area without internal frontiers in which the free movement of goods, persons, services and capital is ensured in accordance with the provisions of the Treaties.").

${ }^{27}$ See Michael Burgess, Territoriality and Federalism in the Governance of the European Union, in STATE TERRITORIALITY AND European InTEgration, supra note 11, at 100; TeSChKe, supra note 11, at 59; STEFANO BARTOLINI, RESTRUCTURING EUROPE 71 (2005).

${ }^{28}$ Buxbaum, supra note 12 , at 636.

${ }^{29}$ See Paulette Kurzer, Market Integration and the Mobility of People: Europeanization of Values and Beliefs, in Globalization AND the European Political Economy 30 (Steve Weber ed., 2001). Note particularly Kurzer's illuminating examples: "A striking discovery, therefore, is that Nordic alcohol control policy is becoming more liberal, that Dutch drug policy is becoming more punitive, and that Irish anti-abortion views are softening."

${ }^{30}$ BARTOLINI, supra note 27 , at 390 .

${ }^{31}$ See, e.g., Regulation 650/2012, of the European Parliament and of the Council of 4 July 2012 on Jurisdiction, Applicable Law, Recognition and Enforcement of Decisions and Acceptance and Enforcement of Authentic Instruments in Matters of Succession and on the Creation of a European Certificate of Succession, 2012 O.J. (L 201) 118.
} 
Member States anymore. Second, many of the Member States have no external borders in the traditional sense, unless they find themselves at the external border of the EU, Schengen complications notwithstanding. ${ }^{32}$ That aspect of EU rule has shifted the focus from hard national borders to the external borders of the EU.

The European Arrest Warrant scheme (EAW), which in principle requires Member States to extradite defendants in criminal proceedings at the request of another Member State, provides a striking example within the AFSJ. Absent specific EU rules, the fundamental normative architecture of the EU-mutual trust among the Member States, sincere cooperation between the EU and Member States, as well as EU citizenship_-means that extradition of a national of another Member State to their home Member State takes precedence over third-country extradition requests. ${ }^{33}$ It thus contains a protective element connected to the EU territory. Priority is given to the home State's decision to prosecute their own nationals before host States can extradite an EU citizen to third countries. The EAW regime at the same time involves diluting the right to stay in one's home country because it lowers the conditions for extradition to another Member State, where one is accused of a crime. In that sense, the EAW is compensation for the free movement rules, stripping the individual citizen of the expectation to be protected in one's home country. ${ }^{34}$ Such extradition intrudes into the very bedrock of the State's protective function. It affects a central link between States and their citizens. Quasiautomatic extradition of one's own national to another State is only possible based on mutual trust in the requesting State's capacity and willingness to secure procedural and substantive fundamental rights, which the EU's institutional machinery facilitates and monitors.

Relatedly, the interaction between EU law and subnational authorities, namely bounded regulatory entities below the State level, reveals a further drop in the importance of national territories and frontiers. Seminal cases from Azores - the Portuguese Azores territories-via Omega-the German city of Bonn - to Walloon Waste-the Belgian region of Wallonia-have led Michèle Finck to conclude that the formally exclusive relationship between the EU and its Member States neither captures the functional permeability of State borders nor the direct relationship between the EU and these subnational authorities adequately. ${ }^{35}$ In other words, by taking the regulatory autonomy of cities and regions seriously as a matter of EU law, the EU roots its authority claims in more local governance structures. That gives these subnational entities an independent voice in European integration, to the effect that State territoriality is more and more sidelined. ${ }^{36}$ In addition to the emergence of a supranational notion of territory from above, EU law's emancipation of subnational territories from below thus reduces the importance of national territory.

\footnotetext{
${ }^{32}$ See ECJ, Case C-9/16, Crim. Proc. Against A, ECLI:EU:C:2017:483 (July 21, 2017), paras. 30-31, https://curia.europa.eu/ juris/liste.jsf?num $=\mathrm{C}-9 / 16$.

${ }^{33}$ See ECJ, Case C-182/15, Aleksei Petruhhin v. Latvijas Republikas G̦enerālprokuratūra, ECLI:EU:C:2016:630 (Sept. 6, 2016), https://curia.europa.eu/juris/liste.jsf?num $=\mathrm{C}-182 / 15$; Jean-Claude Bonichot, Extradition and EU Law: An Unexpected 'Pas de Deux,' in An Ever-Changing Union?: Perspectives on the Future of EU Law in Honour of Allan Rosas 311 (Koen Lenaerts Jean-Claude Bonichot, Heikki Kanninen, Caroline Naômé \& Pekka Pohjankoski. eds., 2019).

${ }^{34}$ See Sara Iglesias Sánchez, A Citizenship Right to Stay: The Right Not to Move in a Union Based on Free Movement, in EU Citizenship and Federalism: The Role of Rights 371 (Dimitry Kochenov ed., 2017); Koen Lenaerts, New Horizons for the Rule of Law Within the EU, 21 GERMAN L.J. 29, 32 (2020).

${ }^{35}$ See ECJ, Case C-120/09, Comm'n v. Belgium, ECLI:EU:C:2009:802 (Dec. 17, 2009), https://curia.europa.eu/juris/liste.jsf? num=C-120/09; ECJ, Case C-36/02, Omega Spielhallen- und Automatenaufstellungs-GmbH v. Oberbürgermeisterin der Bundesstadt Bonn, ECLI:EU:C:2004:614 (Oct. 14, 2004), https://curia.europa.eu/juris/liste.jsf?num=C-36/02; ECJ, Case C-88/03, Portugal v. Comm'n, ECLI:EU:C:2006:511, (Sept. 6, 2006), paras. 54-56, https://curia.europa.eu/juris/liste.jsf? num=C-88/03. See also MiCHÈLE FinCK, SUbNATIONAL AUTHORITIES IN EU LAW chs. 1, 4 (2017). From a democratic theory perspective, see generally Michael Keating, Europe's Changing Political Landscape: Territorial Restructuring and New Forms of Government, in Convergence and Divergence in European Public LaW (Paul Beaumont, Carole Lyons \& Neil Walker eds., 2002).

${ }^{36}$ For an interesting parallel to the treatment of similar issues by the Supreme Court of the United States see Richard T. Ford, Law's Territory (A History of Jurisdiction), 97 MiCH. L. REv. 843, 923 (1999). On the pressure on state sovereignty, from both below and above the state in the EU, see Neil Walker, The Sovereignty Surplus, 18 INT'L J. Const. L. 370 (2020).
} 
Finally, Article 3 (3) TEU contains a curious reference to the Union territory by listing the promotion of "territorial cohesion ... among the Member States" as one of the EU's objectives. It aims to offset inequalities among various regions and thereby actively and explicitly contributes to a coherent development of the polity. ${ }^{37}$ These are not peanuts. The new Multiannual Financial Framework for 2020-2027 allocates more than $€ 426$ billion to cohesion, resilience, and values, which does not even include another $€ 776.5$ billion from the Next Generation EU instrument to tackle the challenges COVID-19 presents to the EU.

The governance technique that pervades these examples resembles the duality between deregulation and reregulation in the internal market, namely the combination of banning unjustified restrictions of fundamental freedoms and the introduction of common rules on the European level. ${ }^{38}$ Piercing the control function of national borders while developing supranational borders shows the same regulatory and structural pattern. The EU thus provides one important illustration of the more general observation that de- and re-territorialization go hand in hand. ${ }^{39}$ Yet, this does not mean that the minus on the Member State level exactly mirrors the resulting plus on the supranational level. Otherwise, by replicating State structures, the EU would be unable to transcend and solve the problems of its Member States. ${ }^{40}$

In sum, the EU designs a common area for the peoples of Europe precisely by legally facilitating the mobility between individual State jurisdictions and thereby devalues the importance of national territoriality, especially of national borders. The effect is that EU membership modifies Member State territoriality permanently because it brings about these changes. Instead of, for example, primacy of EU law, which merely requires to disapply national law within the scope of EU law, EU membership transforms the very idea of national borders and national-territorial rule.

\section{Interim Conclusion: EU Law and Member State Territoriality}

The Treaties express an underlying assumption about the existence of EU territory and the rest, an inside and an outside. Moreover, the EU's territory is parasitic and dependent on the continued existence of national territory. The emerging territorialization of EU rule, which I will further explore below, does not supersede national-territorial rule.

The EU nonetheless transforms the traditional understanding of state territoriality. ${ }^{41} \mathrm{EU}$ law connects national territories, and during that, forms a European territory. The parasitic nature of EU territory creates the conditions for this reflexive relationship in the first place. As we have seen, EU law's aim to create border-transcending regulatory alignment interferes with nationalterritorial rule and the normative salience of national borders. Various examples from private international via the EAW to the EU's relationship to subnational authorities illustrated the diminishing importance of national territory. These are examples of what John Ruggie calls "unbundling" national territory. ${ }^{42}$

In theoretical terms, EU membership forces the Member States to open their bounded territories to the various peoples that have committed themselves to the European project. Following Miller's territorial rights, Member States must share jurisdiction with the EU, lose most of the control over their borders, and provide outsiders access to their resources. The EU's effect on

\footnotetext{
${ }^{37}$ See Eckes \& Wessel, supra note 14, at 89-90; Bialasiewicz, Elden \& Painter, supra note 15, at 345.

${ }^{38}$ See BARTOLINI, supra note 27 , at $375,386,406$. Bartolini seems to agree and calls these elements de- and re-structuring. In his view, however, the restructuring at the EU level is almost negligible.

${ }^{39}$ See Ralf Michaels, Notes on Territory, in Tipping Points In InTERnational LAw 2 (forthcoming Nov. 2021).

${ }^{40}$ Similarly, for security policy, see Francis Cheneval \& Kalypso Nicolaïdis, The Social Construction of Demoicracy in the European Union, 16 EUR. J. POL. TheOry 235, 251 (2017).

${ }^{41}$ See Daniel Innerarity, Democracy in Europe: A Political Philosophy in the EU, 168, 239 (2018). That seems to be a common feature of European integration. See Kalypso Nicolaïdis, European Demoicracy and Its Crisis, 51 J. COMMON MKT. STUD. 351, 360 (2013).

${ }^{42}$ See John Gerard Ruggie, Territoriality and Beyond: Problematizing Modernity in International Relations, 47 INT'L ORG. 139-40, 165 (1993).
} 
State territoriality is hence enormous. The EU does not weaken territorial rule in Europe, but instead renders it richer and more complex. ${ }^{43}$ Think of the traditional function of territory to allocate responsibility to identify the local, regional, or national community responsible in case of an emergency or disaster, an issue closely connected to political authority. ${ }^{44}$ Territoriality aims to create order. ${ }^{45}$ Overlapping territorial jurisdictions necessarily obscure responsibilities. At the same time, they increase the available resources to tackle crises. Only very recently, the EU used the possibility to grant solidarity-aid for unforeseen occurrences under Art 122 TFEU to mitigate the effects of the COVID-19-pandemic with the SURE-Regulation.

This interference into national-territorial rule evidently raises questions of legitimacy. To what extent can the EU rightfully change and suppress the exercise of national territorial rule? Not rarely the very identity of the center relies on identity roots in its smaller communities. ${ }^{46}$ The rationale behind the protection of national identity and territorial integrity in Article 4 (2) TEU is to remind EU actors of the independent value of the various European identities, which should be preserved despite the integration process. This constantly renegotiated bargain between the center and the lower level, as well as the ongoing tension between supranational space and local roots, remains one of the key projects for the ongoing development of the EU polity. The balancing of the two remains a constant legitimacy challenge.

It is accordingly not an exaggeration to claim that EU integration has profound effects on national-territorial rule. Because this process redefines the concept of territorial rule in Europe on both levels, however, one cannot leave out the elements of territorial rule on the EU level itself.

\section{Supranational Territorial Rule: Of Jurisdiction and Borders}

It is important to begin the analysis with the concept of territorial jurisdiction at the EU level. The notion of EU territory plays a remarkable role as trigger for the EU's jurisdiction, and helps to construct a territorial-extraterritorial distinction of EU law's reach. Moreover, the various manifestations of an inside-outside divide on the EU's outer borders give us a clearer picture of the reterritorialization at the supranational level and the ensuing legitimacy challenges.

\section{EU Territory as a Normative Concept: Supranational Territorial Jurisdiction}

The introduction alluded to the notion of territorial jurisdiction as the primary manifestation of territorial rule. Moore has recently described the widespread view according to which the notion of territory itself is intrinsically connected to the right to have and exercise jurisdiction over a distinct patch of the planet that is justified by a particular moral value. In short, "territory is the geographical domain of jurisdictional authority" ${ }^{47}$ Her analysis naturally focuses on states. There, the paradigm of territorial jurisdiction applies in its strongest form to protect states from external influence as part of customary international law. Contrast this with the purely functional jurisdiction of international organizations, where exclusively non-territorial criteria-for example international trade disputes in the WTO case-trigger a given legal regime's jurisdiction. Thus, the inquiry is conceptually prior to the familiar questions of private international law, namely which individual body has jurisdiction, and which substantive law applies in a given case. For what is of interest here is whether and how the EU uses territorial elements to exercise authority

\footnotetext{
${ }^{43}$ See Ulrike Jureit \& Nikola Tietze, Postsouveräne Territorialität: Die Europäische Union als supranationaler Raum, 55 DER StAAT 353, 362 (2016). See generally Pierre Hassner, Fixed Borders or Moving Borderlands?, in EUROPE UNBOUND: ENLARGING AND RESHAPING THE Boundaries of THE EUROPEAN UNION, supra note 13; BARTOLINI, supra note 27, at 368.

${ }^{44}$ See Virginie Mamadouh \& Gertjan Dijkink, Territoriality and the EU Citizen, in STATE Territoriality and EUROPEAN INTEGRATION, supra note 11, at 147, 170; Sánchez, supra note 34, at 387.

${ }^{45}$ See Raustiala, supra note 7 , at 2547.

${ }^{46}$ See Ford, supra note 36, at 867-68, 908.

${ }^{47}$ MoORE, supra note 9 , at 26.
} 
in the first place. In other words, territorial jurisdiction is a theoretical concept that informs how a polity or organization may legally regulate the applicability of its law and what falls under its legitimate regulatory reach.

In relation to territorial jurisdiction, ECJ jurisprudence and secondary law corroborate the interplay between the EU's geographical space and territoriality as governance tool. There is a noticeable development towards elements of territorial jurisdiction at the EU level.

Due to the principle of conferral under Article 5(1) TEU, the EU cannot use territorial triggers alone to justify its jurisdiction. The mere fact that a legal problem arises on the EU territory does not suffice to trigger the EU's jurisdiction. However, as already noted in Section C, the divide between competence and jurisdiction in the EU expands the EU's normative influence on sectors well beyond its written competences. Intriguingly, the ECJ developed an element of EU law's jurisdiction based on an autonomous notion of EU territory. According to the ECJ, the EU Aviation Directive does not infringe the principle of territoriality/sovereignty of the third state:

[S]ince those aircrafts are physically in the territory of one of the Member States of the European Union and are thus subject on that basis to the unlimited jurisdiction of the European Union. ${ }^{48}$

The effect on the Union's geographical territory seemingly suffices to trigger the applicability of EU law. EU secondary law seems to mirror this understanding. For example, the EU legislator uses Union territory as a jurisdiction-defining element prominently in Article 3 (1) General Data Protection Regulation (GDPR). ${ }^{49}$ All these statements presuppose that the EU may legitimately employ territorial triggers for its jurisdiction.

Next, the very existence of extraterritoriality in EU law entails a territorial understanding of jurisdiction because the inside-outside divide itself is responsible for the normative difference. The ECJ has applied EU law extraterritorially for decades. For instance, the freedom of workers applies to employment contracts performed outside the EU as long as they retain a sufficiently close link with the EU territory. ${ }^{50}$ Instead of reasoning based on State territoriality and their jurisdiction alone, ${ }^{51}$ the Court seems to operate with an independent notion of EU territory. Various recent pieces of legislation and the accompanying ECJ jurisprudence illustrate in a comparable

\footnotetext{
${ }^{48}$ ECJ, Case C-366/10, Air Transp. Ass'n of Am. and Others v. Sec'y of State for Energy and Climate Change, ECLI:EU: C:2011:864 (Dec. 21, 2011), para. 125, https://curia.europa.eu/juris/liste.jsf?num=C-366/10. See also ECJ, Case C-424/13, Zuchtvieh-Export GmbH v. Stadt Kempten, ECLI:EU:C:2015:259 (Apr. 23, 2015), https://curia.europa.eu/juris/liste.jsf? num $=\mathrm{C}-424 / 13$. On this jurisdiction-triggering element, see Ford, supra note 36, at 853.

${ }^{49} \mathrm{See}$ Regulation 2016/679, of the European Parliament and of the Council of 27 April 2016 on the Protection of Natural Persons with Regard to the Processing of Personal Data and on the Free Movement of Such Data, and Repealing Directive 95/46/EC (General Data Protection Regulation), art. 3(1), 2016 O.J. (L 119/1) [hereinafter GDPR] (“Territorial Scope: This Regulation applies to the processing of personal data in the context of the activities of an establishment of a controller or a processor in the Union, regardless of whether the processing takes place in the Union or not.").

${ }^{50}$ See ECJ, Case C-36/74, Walrave and Koch v. Association Union Cycliste Internationale and Others, ECLI:EU:C:1974:140 (Dec. 12, 1974), para. 28, https://curia.europa.eu/juris/liste.jsf?num=C-36/74; ECJ, Case C-237/83, SARL Prodest v. Caisse Primaire d'Assurance Maladie de Paris, ECLI:EU:C:1984:277 (July 12, 1984), para. 10, https://curia.europa.eu/juris/liste. jsf?num $=$ C-237/83. The Court's formulations, however, vary. Sometimes, it gives the impression that EU territory as a self-standing concept triggers jurisdiction. See ECJ, Case C-9/88, Lopes da Veiga v. Staatssecretaris van Justitie, ECLI:EU: C:1989:346 (Sept. 27, 1989), para. 15, https://curia.europa.eu/juris/liste.jsf?num=C-9/88; ECJ, Case C-60/93, Aldewereld v. Staatssecretaris van Financiën, ECLI:EU:C:1994:271 (June 29, 1994), para. 14, https://curia.europa.eu/juris/liste.jsf?num= C-60/93. Elsewhere, the jurisdiction focuses on the Member States territory. See ECJ, Case C-214/94, Ingrid Boukhalfa v. Bundesrepublik Deutschland, ECLI:EU:C:1996:174 (Apr. 30, 1996), para. 15, https://curia.europa.eu/juris/liste.jsf?num=C214/94; ECJ, Case C-396/05, Doris Habelt, Martha Möser, and Peter Wachter v. Deutsche Rentenversicherung Bund, ECLI:EU:C:2007:810 (Dec. 18, 2007), para. 122, https://curia.europa.eu/juris/liste.jsf?num=C-396/05. On how this question relates to legitimate political authority, see Andrei Marmor, The Dilemma of Authority, 2 JuRIs. 121, 133 (2011).

${ }^{51}$ Such as in European Court of Human Rights jurisprudence. See Ben El Mahi and Others v. Denmark, App. No. 5853/06 (Dec. 11, 2006), http://hudoc.echr.coe.int/eng?i=001-78692.
} 
way the development of a principled stance on the extraterritorial application of EU law, which affects salient areas like competition, financial regulation, and internet regulation. ${ }^{52}$

There is another intriguing facet to the extraterritoriality of EU law. Extraterritoriality is usually problematic for its intrusion into the regulatory territory of third States. The EU's legislative compromise on the "right to de-referencing" from platforms, for example, does not extend to the platform's worldwide operations because the ECJ recognizes the sensitivity of the otherwise far-reaching extraterritorial effects. ${ }^{53}$ Elsewhere, the noticeable extraterritorial reach of EU law is due to "extra-territorial" triggers for the EU's jurisdiction, like effects, anti-evasion, or transaction. ${ }^{54}$ I would like to call them "a-territorial" triggers, however, because they reflect the inherently functional component in the EU's governance and its competences. By defining the reach of EU law functionally-for example by letting mere effects of financial transactions within the EU suffice-the EU makes territorial claims on third countries. ${ }^{55}$ It imposes legal obligations on them and their businesses. ${ }^{56}$ More territoriality on the part of the EU in the sense of a deliberate restriction of EU law's jurisdiction to the EU territory would paradoxically lead to less interference with third States. In general, the functional way that pervades the EU's governance is inherently susceptible to flout the territorial-extraterritorial distinction so central in the relations among states. ${ }^{57}$

The EU's widespread use of territorial jurisdiction and the effects of extraterritorially applicable EU law on third States thus reveals various interesting features about the EU's architecture. EU territory alone at times suffices to activate the EU's jurisdiction. While EU institutions and academics take it for granted, it is theoretically important that territorial triggers form part and parcel of the EU's jurisdiction. Moreover, the variegated "extraterritorial" application of EU law is not only based on a confident, purely EU law-based application of territory-related triggers, which has hitherto been confined to States. The various functional triggers also impinge on the territorial jurisdiction of third States. This is not to suggest that the EU's jurisdiction-territory nexus mirrors its statist sibling, however. In all these examples, national territory plays a decisive role in triggering and defining the EU's jurisdiction. And yet, these instances exemplify that EU territory matters and-even more simply - that it exists as an independent concept and normative reference point. This jurisdictional element is complemented by a noticeable inside-outside divide in relation to non-Member States.

\section{The EU's Borders and the Creation of an Inside-Outside Divide}

To learn more about the boundaries of the EU's political community, it is important to start once more with a look at the treaties. The treaties mandate a self-standing territorial inside-outside divide, which I touched upon when reflecting on the relationship between de-territorialization and re-territorialization. In particular, Article 77 TFEU-in the context of the AFSJ-requires the absence of controls of persons crossing internal borders and the efficient monitoring of

\footnotetext{
${ }^{52}$ For a comprehensive overview, see generally the collection of essays in MARISE CREMONA \& JOANNE SCOTT, EU LAW BEyond EU Borders: THE EXTRATERritorial REACH OF EU LAW (2019).

${ }^{53}$ See ECJ, Case C-507/17, Google LLC v. Commission nationale de l'informatique et des libertés (CNIL), ECLI:EU: C:2019:772 (Sept. 24, 2019), https://curia.europa.eu/juris/liste.jsf?num=C-507/17; see also ECJ, Case C-18/18, Eva Glawischnig-Piesczek v. Facebook Ireland Ltd., ECLI:EU:C:2019:821 (Oct. 3, 2019), para. 48, https://curia.europa.eu/juris/ liste.jsf?num=C-18/18. But see ECJ, Case C-131/12, Google Spain SL and Google Inc. v. Agencia Española de Protección de Datos (AEPD) and Mario Costeja González, ECLI:EU:C:2014:317 (May 13, 2014), https://curia.europa.eu/juris/liste.jsf? num $=\mathrm{C}-131 / 12$.

${ }^{54}$ See Joanne Scott, The New EU “Extraterritoriality," 51 Common MKT. L. Rev. 1343, sec. 2.2 (2014).

${ }^{55} \mathrm{See}$ id. at sec. 2.2.1.

${ }^{56}$ Scott calls these instances "territorial extension." It goes well beyond the de facto effect of EU law as a global regulatory standard to comply with, as masterfully explained in ANU BRAdFORD, THE Brussels EFFECT: How THE EUROPEAN UNION RULES THE WORLD (2020). For a discussion of the interrelation between these notions, see Joanne Scott, The Global Reach of EU Law, in Cremona \& Scott, supra note 52.

${ }^{57}$ See the various examples in Marise Cremona \& Joanne Scott, Introduction to CREMONA \& SCOTT, supra note 52, at 13.
} 
external borders. The AFSJ not only creates a normatively relevant dichotomy between the inside and the outside. It also establishes quasi-hard borders on the supranational level. ${ }^{58}$ For the evolution of an internal area of freedom resulted in Member States' calls for an area of security and justice towards the outside. ${ }^{59}$ In A. John Simmons' analogy to States as property owners, they designed the EU to look more like a "gated neighborhood." 60 Conversely, the Common Security and Defense Policy has sharpened a territorial element in EU rule with regard to the outside. It allows the EU to use civilian and military means to combat terrorism and other threats "supporting third countries" or for "missions outside the Union". ${ }^{61}$

These elements distinguish the EU from former empires such as the British Empire or the Austro-Hungarian Reich as prior emancipatory polities beyond the traditional State model. ${ }^{62}$ In contrast to empires, the EU relies on concrete external borders rather than a power center with decreasing influence towards the periphery. ${ }^{63}$ But how do these borders influence the EU's authority claim? Insights from political geography help to tackle this question.

The EU's architecture is characterized, much more than in the past, by a territorially fixed political community. In large part, the construction of the $\mathrm{EU}$ is an attempt to create a coherent political, social, and economic space. By nature, bordering is a multilevel process of re-territorialization, which raises important questions regarding the EU's political and territorial nature. ${ }^{64}$

Geographical boundaries play a role in the appreciation of the EU's authority. ${ }^{65}$ First, borders and territory appear to be a precondition for constructing a polity. Simultaneously, they raise questions about its legitimacy because their barriers and fences represent the discrimination between insiders and outsiders. ${ }^{66}$ Second, territorial borders distinguish EU rule from traditionally purely functional international organizations. Scholarly criticism according to which EU law sometimes views the EU's territory as just that - to wit, a geographical space instead of a normative notion-should nonetheless not be overstated. ${ }^{67}$ The EU's manifestation of spatial belonging is clearly both geographical and normative. This points to the tension between Fortress Europe

\footnotetext{
${ }^{58}$ See Alessandro Vitale, The EU's Notion of Territoriality: The "Westphalian Memory" vs. the "New Empire," 2 SEC. Dimensions 59, 64 (2013); William Wallace, Where Does Europe End?, in Europe Unbound: Enlarging And Reshaping THE Boundaries of THE European Union, supra note 13, at 56.

${ }^{59}$ See Bialasiewicz, Elden \& Painter, supra note 15, at 344; Note from Gen. Secretariat of the Eur. Council to Delegations, at 7 (June 20, 2019), https://www.consilium.europa.eu/media/39922/20-21-euco-final-conclusions-en.pdf ("We must ensure the integrity of our territory. We need to know and be the ones to decide who enters the EU. Effective control of the external borders is an absolute prerequisite for guaranteeing security, upholding law and order, and ensuring properly functioning EU policies, in line with our principles and values.").

${ }^{60}$ Simmons, supra note 8 , at 213.

${ }^{61}$ Treaty on the European Union art. 42(1), Feb. 7, 1992, 1992 OJ (C 191) 1 [hereinafter TEU] (“... The Union may use them on missions outside the Union for peace-keeping, conflict prevention and strengthening international security in accordance with the principles of the United Nations Charter... ”); see also TFEU at art. 43 (“... All these tasks may contribute to the fight against terrorism, including by supporting third countries in combating terrorism in their territories.") (emphasis added).

${ }^{62}$ See Vitale, supra note 58 , at 62.

${ }^{63}$ See Mamadouh, supra note 24, at 423; Alessandro Vitale, The Contemporary EU's Notion of Territoriality and External Borders, 18 Eur. SPatial Rsch. Pol'y 17 (2011). Cf. Jan Zielonka, The International System in Europe: Westphalian Anarchy or Medieval Chaos?, 35 J. Eur. Integration 1 (2012).

${ }^{64}$ See Vitale, supra note 58, at 60. See also James Wesley Scott \& Henk van Houtum, Reflections on EU Territoriality and the 'Bordering' of Europe, 28 Pol. GeOgraphy 271, 273 (2009).

${ }^{65} \mathrm{Cf}$. Hans Lindahl, Finding Place for Freedom, Security and Justice: The European Union's Claim to Territorial Unity, EUR. L. REV. 461, 462 (2004) ("whether spurious or authentic, geographical unity is . . irrelevant to an understanding of the unity of a legal space in general.”).

${ }^{66}$ See Hassner, supra note 43, at 35; Jureit \& Tietze, supra note 43, at 356 . For example, moral wrongs in acquiring territory undermines a State's authority over this patch of the planet, see generally CARA NINE, GLOBAL JUSTICE AND TERRITORY (2012).

${ }^{67}$ See, e.g., Loïc Azoulai, Transfiguring European Citizenship: From Member State Territory to Union Territory, in EU Citizenship And Federalism: The Role of Rights, supra note 34, at 178, 202.
} 
and Europe as an ideal, special area of human hope. Claiming a particular space as the territory of the EU involves a point of reference to values that unite those on the inside. ${ }^{68}$ In the background of the technical notion of free movement lurks a common space for Europeans. In that sense, geographic and normative elements of territory depend on each other: The harder the outer borders, the greater the need to unify the inside and to justify exclusion. ${ }^{69}$ Conversely, a more rigorous enforcement of internal values and common standards itself accentuates the internal-external divide.

None of this is to argue that borders are necessarily morally wrong, but merely that they raise the moral profile of a polity. ${ }^{70}$ Take the discussions surrounding the Irish border in the Brexit negotiations. ${ }^{71}$ The imminent scenario of an external EU border on the Irish island provokes the EU-and not the Republic of Ireland alone - to justify its desire for a hard border protecting the EU's inside and to spell out the precise object of its protection. Simultaneously, the EU needs to reconcile that desire with the task to ensure peace and stability on the Irish island. For that reason, a discussion of the EU's territorial authority needs to consider its relationship to States outside the EU. In an important sense, the outer European borders demarcate a European space as well as marking an outer frontier of one of the Member States. This does not contradict this Article's earlier claim that the EU does not control its borders. It merely characterizes the incessant ambivalence of two overlapping jurisdictions where identical borders fulfill distinct functions. Once again, the Brexit negotiations in relation to the Irish border powerfully bring to the fore both geographic and normative manifestations of EU territorial rule. On the one hand, there is the fear of a hard outward border with all its conflict-driving potential. On the other hand, there is the aspirational promise of an area of free movement and common values, which the EU has hitherto contributed to securing on the Irish island. The Irish border discussion shows that the European frontiers mark more than the end of a trading block. They usually mark the end of a common space for the European peoples.

\section{Interim Conclusion: The Normative Significance of the EU's Territory}

This section focused on the supranational component of the EU's territoriality. EU institutions use territorial jurisdiction, an inside-outside distinction, to determine the applicability of EU law. In many ways, on both the national and the supranational level, "territoriality remains the main control mechanism in the European Union."72

This legal observation is corroborated by various moral consequences of this supranational reterritorialization into a "gated neighborhood." The internal openness through overcoming physical and regulatory borders coincides with a substantial outward exclusion. It replicates a territorially bounded architecture as a direct consequence of opening up statist territories. ${ }^{73}$ This dichotomy creates moral problems of exclusion and raises the need to justify the divide. Brief excursions into political theory have shown that the harder the border, the more pressing the need to demonstrate the reason for protecting the inside.

To grasp the territorial element of EU rule more fully, it is important to view the role of EU citizens next.

\footnotetext{
${ }^{68}$ See Lindahl, supra note 65, at 468. See generally Ford, supra note 36, at 844 ("Jurisdiction defines the identity of the people that occupy them."). See also Simmons, supra note 8, at ch. 10.

${ }^{69}$ See Koen Lenaerts, La vie après l'avis: Exploring the Principle of Mutual (Yet Not Blind) Trust, 54 CoMmON MKT. L. REv. 838 (2017).

${ }^{70}$ For example, in a world State that treats minorities unjustly, secession as a potential remedy to bordered polities would not be available. See Thomas Christiano, A Democratic Theory of Territory and Some Puzzles about Global Democracy, 37 J. Soc. PHIL. 81, 104 (2006). On the conceptual necessity of borders in a legal order, see Paulina Ochoa Espejo, Why Borders do Matter Morally: The Role of Place in Immigrants' Rights, 25 Constellations 71, 79 (2018).

${ }^{71}$ For a brilliant overview see Stephen Weatherill, The Protocol on Ireland/Northern Ireland: Protecting the EU's Internal Market at the Expense of the UK's, 45 Eur. L. REV. 222 (2020).

${ }^{72}$ Mamadouh, supra note 24 , at 424.

${ }^{73}$ See Jureit \& Tietze, supra note 43 , at 364 . However, I would not use their descriptor "post-sovereign territory."
} 


\section{E. How EU Citizens Shape the EU's Territorial Rule}

This Article has already shown how free movement as a central idea in the EU's governance has a profound effect on national territorial rule. It is worth spending more time on the specific role of EU citizens in emerging elements of supranational territoriality. Indeed, one of the most remarkable examples for an evolving normative concept of territoriality in the EU stems from the Court's coupling of membership and territory in Zambrano. Moreover, the fact that EU law gives exit rights to EU citizens triggers a whole range of territory-related legitimacy questions.

\section{The Link Between EU Membership and Territoriality}

The introduction of EU citizenship considerably raised the normative salience of the EU's territory. It led to a situation in which the decision to reside in another Member State by itself triggers the application and thereby the protective rights of EU law. ${ }^{74}$ To highlight the importance of this development, this section will briefly elaborate on the most vivid and undoubtedly exceptional manifestation of the thus created link between membership and territorial rule in the EU: The Zambrano case. According to Zambrano, a Member State is not allowed to refuse third country national parents a right of residence if that meant that their children-Member State nationals and therefore EU citizens - would, thereupon, be forced to leave the EU territory as a whole. ${ }^{75}$ In a surprising conceptualization of EU territory, the Court links the "genuine enjoyment of the substance of the rights" of EU citizens to the entire territory of the EU and thereby conjoins membership and territorial rule. ${ }^{76}$ In contrast to the "territory of the Member States" language of Article 20 (2) TFEU, the ECJ refers to "EU territory" in the singular. ${ }^{77}$ Consequently, EU law does not prohibit expulsion of an EU citizen to another Member State because what matters is the EU territory in its entirety. ${ }^{78}$ Only the threat of expulsion from the entire EU territory triggers the jurisdictional essence of EU citizenship rights and thereby the scope of EU law.

In essence, EU law interferes with residency decisions on the national level in order to uphold the minimum guarantees of the status of being a member of the EU polity. This questions an interpretation where EU territory matters exclusively in its relation to mobility and circulation. ${ }^{79}$ In the undoubtedly exceptional circumstances outlined in Zambrano, EU citizenship serves as the sole trigger to invoke the jurisdiction and protection of EU law against the home Member State. That notwithstanding, EU citizenship does not purport to interfere with national or international

\footnotetext{
${ }^{74}$ See Julio Baquero CruZ, What's Left of the LaW of Integration?: DeCAy and Resistance in European Union LAW 95 (2018).

${ }^{75}$ ECJ, Case C-34/09, Gerardo Ruiz Zambrano v. Office national de l'emploi (ONEm), ECLI:EU:C:2011:124 (Mar. 8, 2011), para. 44, https://curia.europa.eu/juris/liste.jsf?num=C-34/09 ("It must be assumed that such a refusal would lead to a situation where those children, citizens of the Union, would have to leave the territory of the Union in order to accompany their parents. Similarly, if a work permit were not granted to such a person, he would risk not having sufficient resources to provide for himself and his family, which would also result in the children, citizens of the Union, having to leave the territory of the Union. In those circumstances, those citizens of the Union would, in fact, be unable to exercise the substance of the rights conferred on them by virtue of their status as citizens of the Union.").

${ }^{76} I d$. at para 42. See also ECJ, Case C-165/14, Alfredo Rendón Marín v. Administración del Estado, ECLI:EU:C:2016:675 (Sept. 13, 2016), https://curia.europa.eu/juris/liste.jsf?num=C-165/14; ECJ, Case C-304/14, Sec'y of State for the Home Dep't v. CS, ECLI:EU:C:2016:674 (Sept. 13, 2016), https://curia.europa.eu/juris/liste.jsf?num=C-304/14.

${ }^{77} \mathrm{TFEU}$ at art. 20(2) ("Citizens of the Union shall enjoy the rights and be subject to the duties provided for in the Treaties. They shall have, inter alia: (a) the right to move and reside freely within the territory of the Member State...”).

${ }^{78}$ This point is clarified in in ECJ, Case C-86/12, Adzo Domenyo Alokpa and Others v. Ministre du Travail, de l'Emploi et de l'Immigration, ECLI:EU:C:2013:645 (Oct. 10, 2013), https://curia.europa.eu/juris/liste.jsf?num=C-86/12; ECJ, Case C-434/ 09, Shirley McCarthy v. Sec'y of State for the Home Dept., ECLI:EU:C:2011:277 (May 5, 2011), https://curia.europa.eu/juris/ liste.jsf?num=C-434/09; ECJ, Case C-256/11, Murat Dereci and Others v. Bundesministerium für Inneres, ECLI:EU: C:2011:734 (Nov. 15, 2011), https://curia.europa.eu/juris/liste.jsf?num=C-256/11.

${ }^{79} \mathrm{Cf}$. Serhat Karakayali \& Enrico Rigo, Mapping the European Space of Circulation, in The Deportation Regime: Sovereignty, Space, And the Freedom of Movement 140 (Nicholas De Genova \& Nathalie Peutz eds., 2010).
} 
law's protection of the territorial rights of citizens against their own State of nationality. As the Court held:

[A] principle of international law precludes a Member State from refusing its own nationals the right to enter its territory and remain there for any reason .... [T] hat principle also precludes that Member State from expelling its own nationals from its territory or refusing their right to reside in that territory or making such right conditional. ${ }^{80}$

The Zambrano jurisprudence implies that the ECJ structurally aligns EU citizenship with a core element of national citizenship, namely representing membership in a polity via residence within a given territory. This jurisprudence evidently does not bode well with the Member States' sovereignty claims because the Court in effect curbs the jurisdiction of Member States over their own nationals to the extent that the exercise of such jurisdiction would de facto render EU citizenship moot. It constitutes an interesting twist that the subsidiary protection of Zambrano supports the home Statenational citizen relationship, given that de facto expulsion of one's own national/EU citizen is prohibited. ${ }^{81}$ Beyond that, the notion of EU citizenship contributes to the explored territorialization of EU rule in other, practically far more relevant, ways, especially in relation to free movement.

\section{Free Movement and Exit Rights}

The territorial flexibility of EU citizens that results from their free movement rights not only contributes to territorial cohesion in the EU, as shown above. It also reconfigures the normative relationship between citizens and Member States.

Note the conceptual connection between free movement and exit rights. Ever since Locke's argument for justifying political authority by recourse to tacit consent, exit rights entered the debate of legitimate political authority. Locke derived tacit consent to the state's legitimate authority from a citizen's refusal to leave the territory of their State. ${ }^{82}$ By continuing to live in a state, citizens imply that they silently approve of the state's rule, which renders it legitimate. Unsurprisingly, various theorists have explained how exit rights do not license mistreatment, such as - in the extreme case-a permission to violate fundamental rights of minorities on the basis that they can always leave the state in question. ${ }^{83}$ However, even a lower threshold suggests that exit rights are no guarantor for the well-being and autonomy of the individuals given that personal, economic, or ascriptive factors can make the exercise of exit rights extremely burdensome. ${ }^{84}$ So, how does EU citizenship come into the equation?

EU citizenship fundamentally redesigns the exit option for citizens of the Member States. In a sense, the EU makes the exit right a real, viable option for EU citizens. It offers the entire EU territory to the EU citizens. Not in the strong sense of dual citizenship, in which case the citizen could enjoy the same rights in both states. ${ }^{85}$ However, EU citizenship enables the citizen to enter and reside in other Member States with remarkable ease. It favors the exit-possibility over

\footnotetext{
${ }^{80}$ To review the rest of the court's judgement, see McCarthy, Case C-434/09 at para. 29. See also International Covenant on Civil and Political Rights art. 12, Dec. 16, 1966, 999 U.N.T.S. 171 [hereinafter ICCPR]. Many national constitutions guarantee the right to residence as well. See, e.g., Grundgesetz [GG] [Basic Law], art. 11, translation at http://www.gesetze-im-internet.de/ englisch_gg/index.html.

${ }^{81}$ See Sánchez, supra note 34, at 380. Similarly, the legal duty to take back "bad citizens" from host States fits into this logic. See Azoulai, supra note 67, at 199-200.

${ }^{82}$ See John Locke, Two Treatises of Government and a Letter Concerning Toleration Second Treatise 152, para. 119 (Ian Shapiro ed., 2003).

${ }^{83}$ See David Hume, Of the Original Contract, in Essays, Moral, Political, And Literary 474 (Eugene Miller ed., 1985). See also John Rawls, Political Liberalism 221-22 (2005).

${ }^{84}$ See Leslie Green, Rights of Exit, 4 LEgal THEOry 165, 174 (1998).

${ }^{85}$ For a vivid illustration of the current limits of EU citizenship rights, see CRUZ, supra note 74, at 105.
} 
Hirschman's alternative to express discontent over the political regime of one's home State: Voice. ${ }^{86}$ The onus of change thus flips back to the home Member State. The viable exit option for citizens and businesses to the other Member States, combined with the voice EU citizenship gives them in host states, creates a competitive environment for these states to keep those citizens and economic agents happy. ${ }^{87} \mathrm{~A}$ Member State may react to the pressure of free movement by benevolent policies for mobile workers to the detriment of immobile workforces, or by encouraging free movement in times of economic crises to counter unemployment, thereby putting the citizen in charge of improving the situation. ${ }^{88}$ This competition facilitates a constant renegotiation of the social contract in the Member States while simultaneously strengthening-since the Member State is forced to care about its citizens-and weakening-since it is easier to leave the state-the bond between a citizen and their home State. The buzzword for this competition in the EU is free movement.

Enabling EU citizens to vote with their feet by moving to another Member State not only realizes a distinct idea of justice by helping EU citizens to pursue their idea of a "good life" elsewhere. ${ }^{89}$ It also constitutes one of the EU's most significant legitimacy-related innovations with profound effects on both national-territorial rule and the development of supranational territoriality.

\section{Interim Conclusion}

Article 20 TFEU entails a right to reside in one's home State under the Zambrano case law's narrow conditions that complements international law's broader protection of the right to stay there. In short, Article 20 TFEU protects the right not to move. By contrast, Article 21 TFEU creates a right to move to, reside in, and be integrated into the host State. Article 21 TFEU protects movement. Both complement each other to grant a minimum right to stay in the entire Union territory with varying levels of EU law protection beyond that. ${ }^{90}$ This jurisprudence thus charges the EU territory with normative value.

These two components forcefully illustrate the influence of EU citizenship on developing a supranational notion of territoriality. For one, EU law gives EU citizens a qualified right to residence on the entire EU territory, which does not entail a right to reside in every Member State, but a right not to be expelled from the EU territory in its entirety. For another, relocating to a different Member State immediately loosens the jurisdictional ties of EU citizens to their home State while creating new such ties to the host State.

This brings us to the final element of the EU's territoriality. Considerable functional flexibility pervades the territorial architecture of the EU, which perhaps more than any of the other elements illustrates the sharp contrast between the EU and the territorial claims of even federal States.

\section{F. Territorial Functionalism, or the Many Territories of Europe}

Instances of territorial rule do not exclude non-territorial governance elements. The most prominent of the latter, certainly in the EU context, is functional rule. Apart from the functional

\footnotetext{
${ }^{86}$ See BARTOLInI, supra note 27, at 378-379. See generally AlBERT O. HirSCHMAN, EXIT, Voice, AND LOYALTY: RESPONSES to Decline in Firms, Organizations, and States (1970). In short, Hirschman analyses the viability of two alternative strategies to react to frustration in an organization or polity, namely, raising concerns internally (voice) or leaving the organization (exit), and how loyalty might affect those.

${ }^{87}$ For an interesting application related to the German reunification, see IVAN KRASTEV \& STEPHEN HOLMES, THE LigHT That Failed: A RecKoning 29-30 (2019).

${ }^{88}$ See Sánchez, supra note 34 , at 379-80.

${ }^{89}$ See Floris De Witte, Justice in the EU: The Emergence of Transnational Solidarity 61-65 (2015).

${ }^{90}$ See Sánchez, supra note 34, at 378, 387; Päivi Johanna Neuvonen, EU Citizenship and its "Very Specific" Essence: Rendón Marin and CS, 54 COMMON MKT. L. REV. 1201, 1211 (2017). Under international law, there remains an asymmetry between the right to leave one's home State without necessarily gaining a right to access somewhere else.
} 
elements in the way the EU exercises its competences, the notion of EU territory itself is inherently functional, which distinguishes it sharply from state territorial rule.

\section{Functional Governance}

Functional governance means "designed to serve a function," ${ }^{\prime 1}$ which is, to repeat, the traditional domain of international organizations. They are created and intended to serve a functional, delimited mandate. This definition makes such an entity's inherent limits evident because the scope of action of the entity is confined to serving that purpose. Much ink has been spilled on the degree of the EU's purported emancipation from its functional origins. ${ }^{92}$ This Article is interested in how functional elements in the EU's architecture interact with the above territorial elements and thus add further contours to its authority claim. ${ }^{93}$

As is well known, many of the EU's core competences are functional. Instead of delimiting a certain substantive regulatory activity, they formulate a regulatory goal that usually transcends various individual sectors. ${ }^{94}$ We saw earlier how this leads to a de-territorialization of national rule. For example, Article 114 TFEU as the core legal basis in internal market matters encompasses the regulation of innumerable sectors, if they "approximate the provisions of law ... which have as their object the establishment and functioning of the internal market." We further uncovered that functional triggers enable EU law to have extraterritorial effect and influence the regulatory autonomy of third States. This pervasive functional element complements the above-mentioned territorial rule and makes demarcating the precise reach and limits of the EU's authority a tricky task. As explained, EU law's oft functional architecture enables the penetration of core elements of national territorial rule in the first place.

\section{The "Variable Geometry" of EU Law}

In remarkable contrast to States as unitary and territorially bounded entities, there seems to be a variety of functionally driven European territories. That makes territorial flexibility an element of the EU's DNA. ${ }^{95}$ Put differently, much of the EU's territorial rule is inherently functional itself.

Consider the possibilities for differentiated integration from opt-outs to enhanced coordination on the primary-law level. Opt-outs — enacted as protocols to the treaties-allow a Member State to be exempt from certain fields of action, such as the common currency. Conversely, enhanced coordination creates the possibility for a group of Member States to deepen integration in specific fields without the non-participating Member States. The result is remarkable. Only six Member States currently partake in the entirety of EU action. ${ }^{96}$ This "variable geometry" continues at the level of secondary law, where the room to maneuver when implementing directives and explicit derogations in secondary law contribute to the uneven application of EU law in the Union territory. ${ }^{97}$

\footnotetext{
${ }^{91}$ Functional, OXFORD ENGLISH Dictionary (3d ed. 2017).

${ }^{92}$ It is almost undisputed that the EU/EEC was a non-territorial, functional entity to begin with. Cf Lindahl, supra note 65 , at 476.

${ }^{93}$ For an in-depth discussion of functional and territorial strategies for a political restructuring of the EU, see BARTOLINI, supra note 27 , at 386.

${ }^{94}$ For how this influences broader questions of legitimacy, see Gareth Davies, Democracy and Legitimacy in the Shadow of Purposive Competence, 21 EUR. L.J. 2 (2015).

${ }^{95}$ See Alberto Miglio, Differentiated Integration and the Principle of Loyalty, 14 Eur. Const. L. ReV. 475, 477 (2018). For historical evidence, see Ziller, supra note 17.

${ }^{96}$ See Floris De Witte, Interdependence and Contestation in European Integration, 3 EUR. PAPERS 475, 493 (2018). On functionally similar options in international law, such as reservations, and their impact on international authority, see BAŞAK CALI, The Authority of International Law: Obedience, Respect, and Rebuttal 109 (2015).

${ }^{97}$ See Bruno De Witte, Variable Geometry and Differentiation as Structural Features of the EU Legal Order, in BETWEEN Flexibility and Disintegration: The Trajectory of Differentiation in EU Law (Bruno de Witte, Andrea Ott \& Ellen
} 
Underneath these options of contractual fine-tuning lies an even more fundamental territorial flexibility. The possibilities to accede to and leave the EU contrast categorically with territorial shifts at the State level. ${ }^{98}$ While the latter is often characterized by secession and war-recall the renewed war between Armenia and Azerbaijan about Nagorno-Karabakh in the EU's neighborhood)_EU membership is not a territorial zero-sum game in the sense that States would lose their self-standing territory. As the Treaties make clear this represents one of the most apparent instances where the EU lacks control over its territory..$^{99}$ And it has a considerable influence on framing the quest for the EU's legitimate authority. Because the EU allows the "secession" of an entire Member State's people. In other words, the EU itself provides more remedies to unjust treatment than States do. ${ }^{100}$ In a sense, the EU takes the peoples' continued consent to the EU project dead serious on a theoretical level, though Brexit has evidenced the myriad practical problems associated with the decision to leave.

A view of the EU's external relations further supports this picture of flexibility. In fact, the territorial flexibility noticed internally applies externally as well. From the European Economic Area (EEA) to the Bilateral Agreements with Switzerland, contractual arrangements export the application of EU law to neighboring States and thereby enlarge the territorial reach of EU law. This leads to awkward qualifications of third States as "almost - but not quite - internal."101 This export of EU law results in flexibility towards both Member States and adjacent States. Only recently, the close alliance between the EU Member States and Iceland as a European Free Trade Area (EFTA) State led the Court to conclude that national courts have to inform EFTA States about a pending extradition request from a third state concerning one of their citizens, and give priority to a surrender request from that EFTA-State. ${ }^{102}$ The Court remarkably extended the Petruhhin rationale that prioritizes intra-EU surrender over third-country extradition requests to cover the EEA members, which concluded extradition agreements with the EU. The important point for present purposes is that the territorial entanglement of some neighboring States with the EU allows these non-Member States to profit from one of the most salient features of the EU's territorial rule, namely the European Arrest Warrant and its priority over third country extradition requests. The nexus between EU law and territoriality thus goes beyond the EU's borders.

\section{Interim Conclusion: Relative Territoriality}

To sum up, all these elements lead to territorial flexibility or "weak territoriality" 103 that is alien to any conceivable form of territorial sovereignty. The above elements of the territorial rule have not led to a uniform regulatory space, where all European laws apply to the entire territory and only to the Union's territory. Instead, the EU consists of a variety of spaces, areas, regions, and networks.

\footnotetext{
Vos eds., 2017); Alberta M. Sbragia, Territory, Representation, and Policy Outcome: The United States and the European Union Compared, in Restructuring Territoriality: Europe and the United States Compared 219-20 (Christopher K. Ansell \& Giuseppe Di Palma eds., 2004).

${ }^{98} \mathrm{See}$ TEU at art. 49(1) ("Any European State which respects the values referred to in Article 2 and is committed to promoting them may apply to become a member of the Union ... ”). See also TEU at art. 50(1) ("Any Member State may decide to withdraw from the Union in accordance with its own constitutional requirements.").

${ }^{99}$ Another element that confirms this is the parasitic nature of the EU's territory discussed at the outset of this Article.

${ }^{100}$ For a discussion, see Christiano, supra note 70 , at 99-100.

${ }^{101}$ Marise Cremona, Extending the Reach of EU Law: The EU as an International Legal Actor, in CREMONA \& SCOTT, supra note 52, at 88 . For a recent study of various regimes, see MARJA-LIISA ÖBERG, THE BOUNDARIES OF THE EU INTERNAL Market: Participation Without Membership (2020).

${ }^{102}$ See ECJ, Case C-897/19, Ruska Federacija v. I.N., ECLI:EU:C:2020:262 (Apr. 2, 2020), https://curia.europa.eu/juris/liste. jsf?num $=$ C-897/19.

${ }^{103}$ Christopher K. Ansell, Territoriality, Authority, and Democracy, in RestruCtURING TERRITORIALITY: EUROPE AND THE UNITED STATES COMPARED, supra note 97, at 227.
} 
And while that may be deplorable from the perspective of unity and uniformity, it has the normative advantage of accommodating very different visions of EU integration in the Member States ${ }^{104}$ as well as idiosyncratic understandings of domains which any national demos wants to protect, such as military neutrality or one's own currency.

The eventual territorial configuration of the EU thus remains a priori unfixed because it is bound to vary following accessions to or exits from the EU. ${ }^{105}$ The scope of EU law moreover does not overlap with its territorial reach. This decoupling of coincidental territorial and regulatory rule constitutes a central feature of, rather than a deficiency in, the EU's architecture. ${ }^{106}$ It evidences the delicate balance between preventing cherry-picking and endorsing the legitimating force of such liberating flexibility. ${ }^{107}$

This forcefully illustrates not only the theoretical contrast between the EU's territorial rule and State territoriality, but also how these functional elements mitigate various of the above elements and thus soften the EU's territorial claims as a whole. The full picture is thus a relative one. ${ }^{108}$ The in-built territorial flexibility weakens the uniform and coherent application of EU law I described earlier. The rather hard border that the AFSJ creates and the complementing mechanisms explained previously are pierced by the web of legal relations to third States. The EU's territorial claims thus intertwine territorial cohesion with functional options. Conversely, the EU's authority has both functional and territorial limits. ${ }^{109}$

Before focusing on the legitimacy challenges the EU's territorial claims trigger, let me reiterate the main findings of our journey through the land of Europe.

\section{G. Summary: The EU's Territorial Claims}

Where does this leave us regarding an account of the EU's territorial claims? The analysis so far shows that we need to meet sweeping statements according to which the end of the law-territory nexus in Europe is nigh with a certain caution. ${ }^{110}$ The EU defies cosmopolitan hopes for the decline of bounded authority in Europe and the belief that spatial frontiers are a relic of the past. Instead, the EU develops its own model of territorial rule. Similarly, labeling the EU a "deterritorialized demoicracy"111 misses the point by neglecting the re-territorializing aspects and the EU's respect for and effects on national territory. This distinguishes the EU from traditional international organizations when it comes to territoriality. For the UN and the WTO do not claim any territorial authority. They do not represent or administer a bordered political space in any normatively relevant way.

Vice versa, describing the EU's territorial claims as "(quasi-) national authority" is equally unwarranted because it neglects the qualitative differences to statist territoriality. ${ }^{112}$ The above elements of re-territorialization do not mimic State territoriality and the EU's strategy of territorial control departs considerably from its manifestation in nation States. ${ }^{113}$ Despite the far-reaching

\footnotetext{
${ }^{104}$ See De Witte, supra note 96 , at 10.

${ }^{105}$ See InNERARITY, supra note 41, at 168-69; Mamadouh \& Dijkink, supra note 44, at 151.

${ }^{106}$ See BARTOLINI, supra note 27 , at 375 .

${ }^{107}$ See Neil Walker, Flexibility Within a Metaconstitutional Frame: Reflections on the Future of Legal Authority in Europe, in Constitutional Change in the EU: From Uniformity to Flexibility?, supra note 17, at 9, 29.

${ }^{108}$ This seems to be an inherent feature of EU rule. See STEPHEN WEATHERILL, LAW AND VALUes IN THE EUROPEAN UNION 69, 155, 172, 255 (2016).

${ }^{109}$ See Moreno-Lax \& Costello, supra note 15, at 1667; Neil Walker, The Idea of Constitutional Pluralism, 65 MOD. L. REV. 317, 346-47 (2002).

${ }^{110}$ See, e.g., René Barents, The Autonomy of Community Law 244 (2003) (“The almost sacrosanct relationship between law and territory, which dates back from the emergence of the sovereign state in the late Middle Ages, is thus severed.").

${ }^{111} \mathrm{Cf}$. Samantha Besson, Deliberative Demoi-cracy in the European Union: Towards the Deterritorialization of Democracy, in Deliberative Democracy and its Discontents 184 (Samantha Besson, José Luis Martí \& Verena Seiler eds., 2006)

${ }^{112} \mathrm{Cf}$. Eckes \& Wessel, supra note 14 , at 89.

${ }^{113}$ See Ziller, supra note 17 , at 114-15 (concluding that the EU-like its predecessors-has no territory of its own).
} 
impact of these territorial elements of the rule, the EU does not claim full control over the Union's territory. Rather, it claims its limited share of control. Perhaps we can adapt Sack's metaphor, in which he compares the difference between personal and territorial rule to parents trying to prevent their children from playing with unsuitable items. Parents could either explain or ban each item individually. Alternatively, they might as well lock them up in a room. ${ }^{114}$ In terms of this Article, the EU represents a building with twenty-seven accessible rooms. It retains an outer boundary while opening the individual rooms to be used jointly. Naturally, such an arrangement makes it more complicated to decide which objects are for common use and which are not. In other words, it makes it more complicated to delimit jurisdiction and competences.

Ruggie thus correctly claimed that territorial rule neither historically nor conceptually necessarily entails exclusivity or mutual exclusion. ${ }^{115}$ The EU creates a framework with complementary and sometimes conflicting notions of territory in distinct yet interrelated polities. The EU, in essence, claims the authority to pierce strong statist notions of territorial rule in the service of a looser, though equally bounded reconceptualization on the EU level, ultimately in an attempt of supranational polity formation. The table below will help visualize the individual elements.

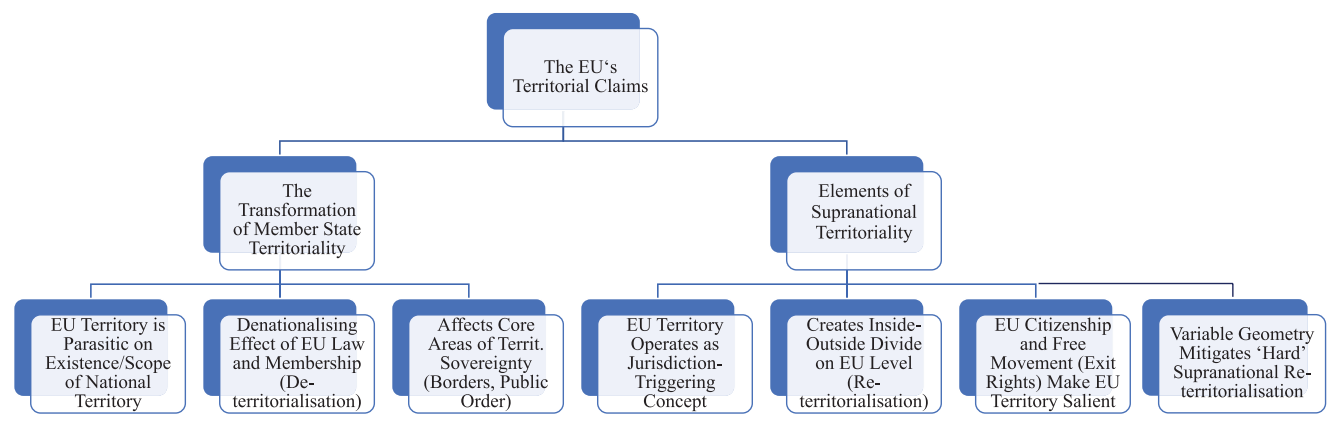

Alas, this overview shows that it remains difficult to pin down the EU's conception of territorial rule. I deliberately refrain from labelling it. The evidence of the individual elements of the EU's conception of territoriality above suffices to understand what the EU's territorial claims involve. In relation to the State, Ralf Michaels has shown very recently how territorialization not only creates both sovereignty and territory as well as their interrelationship in a "strange loop." ${ }^{116}$ It also influences the legitimacy of this bond. An equivalent process is occurring in the EU. By that I mean that the EU's territorial claims induce a territorialization that affects the EU's authority claim and on a specifically European notion of territory that is thereby created. This normative chain leads to the issue of legitimacy, for example, issues as to whether these territorial claims are valid. More succinctly, do we have a theory that explains the moral grounds of the EU's territorial rule?

\section{H. In Search of the Legitimacy Basis for the EU's Territorial Claims}

The main task of this Article so far was to uncover and analyze the EU's territorial claims. While most territoriality theorists on the State level agree on the substance of the territorial rights a typical State claims, I have shown that the same cannot be said about the EU. The EU's territorial claims are comparatively undertheorized. While studying these claims, we came across various

\footnotetext{
${ }^{114}$ See Sack, supra note 13, at 56.

${ }^{115}$ See Ruggie, supra note 42, at 149.

${ }^{116}$ Michaels, supra note 39 , at 9.
} 
legitimacy challenges, such as their profound effect on national territorial rule, the need for justifying an increasing inside-outside divide across normatively salient EU borders, or the recalibration of the EU citizens' relationships to home and host States. The bigger question this survey raises, though it cannot fully answer in the present Article, is: Does the EU have a right to these territorial claims?

In this context, Charles S. Maier asked pointedly: "Yet without ethnicity, what is left to animate a sense of territory?"117 For some, a "community of values" based on Article 2 TEU explains what holds the bounded place of the EU together. ${ }^{118}$ This is not to suggest that the same has been true since the creation of the European Communities. The values in Article 2 TEU nevertheless become ever more prominent in the configuration of the EU's authority claim, especially in their evocation by the EU institutions. ${ }^{119}$ In a similar vein, Lindahl argues that a bounded territory necessarily contains a claim to commonality in the sense that the EU's territory becomes "the EU's own place" through the selection of values that unite those on the inside. ${ }^{120}$

Because the very same values form part of the constitutional orders of the Member States whence they derive, it seems that values like democracy, rule of law, equality, ${ }^{121}$ and fundamental rights per se cannot serve as the sole basis for the EU's territorial claims. For that would allow the Member States to prioritize their national, idiosyncratic understandings of these values, which have historically found their genuine expression in such national political communities. In other words, despite their moral importance, these values seem too feeble to animate and legitimize the remarkable territorial claims described earlier.

A more promising route in the search to legitimize the EU's territorial claims lies in the capacity of the EU to provide a political community beyond the State best understood as a demoicracy, as a forum for the European peoples to govern "together but not as one". ${ }^{122}$ In developing this idea, it is necessary to translate recent scholarship on the moral grounds of a State's territorial rights to the supranational level. There, David Miller argues that the collective demos gives meaning to a place and underwrites territoriality. In his view, the national people ultimately bear territorial rights. ${ }^{123}$ Margaret Moore similarly argues that territoriality provides a political community with a mechanism to exercise normative control over a bordered space, which enables it to express a specific idea(l) of how it intends to live there. ${ }^{124}$ She explicitly connects territoriality to popular sovereignty. Anna Stilz agrees with these theorists on the relevance of popular self-determination for the territorial sovereignty of States. In her account of political autonomy, a legitimate territorial State allows a people to realize the shared commitment to living in a joint community respecting individual and collective self-determination. ${ }^{125}$ Despite important differences among these accounts, they all find the legitimacy basis of a State's territorial rights in various forms of popular self-determination, for example, the moral relationship among the citizen that share the respective territory.

\footnotetext{
${ }^{117}$ Maier, supra note 13 , at 28 . His answer is to perceive of the collective enterprise as a community of risk, committed to the distribution of resources.

${ }^{118}$ See, e.g., Azoulai, supra note 67, at 192; Keating, supra note 35, at 11.

${ }^{119}$ See ECJ, Case C-64/16, Associação Sindical dos Juízes Portugueses v. Tribunal de Contas, ECLI:EU:C:2018:11 (Feb. 27 , 2018), https://curia.europa.eu/juris/liste.jsf?num=C-64/16; Resolution of 16 January 2020 on Ongoing Hearings Under Article 7(1) of the TEU Regarding Poland and Hungary (2020/2513(RSP)), EUR. PARL. Doc. P9_TA(2020)0014, at 2 (2020), https://www.europarl.europa.eu/doceo/document/TA-9-2020-0014_EN.pdf.

${ }^{120}$ Lindahl, supra note 65 , at 468

${ }^{121}$ See TEU at art. 2 ("The Union is founded on the values of respect for human dignity, freedom, democracy, equality, the rule of law and respect for human rights, including the rights of persons belonging to minorities. These values are common to the Member States in a society in which pluralism, non-discrimination, tolerance, justice, solidarity and equality between women and men prevail.").

${ }^{122}$ Nicolaïdis, supra note 41 , at 351.

${ }^{123}$ See Miller, supra note 8 . Regarding borders as a precondition of democracy, see ERIK ODDVAR ERIKSEN, THE Normativity of THE EUROPEAN UNION 109 (2014).

${ }^{124}$ See MOORE, supra note 9, at 196.

${ }^{125}$ See STILZ, supra note 10 , at chs. 4,5 .
} 
Translated to the EU level, this implies that we need to search for a morally significant relationship between the EU and its subjects that allows the EU to claim territory in the first place. Because there is no single EU demos, it will not be in the same way as States relate to their people as a single collective. However, in light of the qualitatively weaker claims the EU makes, it does not have to be. Instead, the EU is supported and run by a collective of collectives, namely the European demoi, which remain organized and constituted separately in and as statist political communities. As we have seen earlier, part of the nature of EU territoriality is its infection by the choices and values of the peoples who have mutually opened their borders to each other. Thus, the justification for the internal-external divide in Europe could perhaps derive from the idea that the EU marks a place for the peoples of Europe and allows them to relate to each other as equals. EU borders would consequently base their moral significance on the way in which they facilitate how the EU peoples jointly exercise their self-government. The EU's territorial claims would be an expression of a moral community defined by the interdependence of self-governing peoples. ${ }^{126}$

Recent literature has started to explore this path. For example, Richard Bellamy scrutinizes the legitimacy of the EU's variable geometry discussed above from a particular demoicratic perspective he calls "republican intergovernmentalism." ${ }^{27}$ In his view, the various instances of differentiated integration can be demoicratically justified because and to the extent they realize three important values: Fairness, impartiality, and equity. ${ }^{128}$ Bellamy thereby rightly emphasizes how the demoicratic architecture of the EU respects the popular self-determination of the individual demoi on the national level and takes their heterogeneity into account. But why focus only on differentiated integration? Demoicracy is a promising theoretical lens concerning the evaluation of the entirety of the EU's territorial claims discussed above. This is especially true for more robust versions of demoicracy that emphasize the value of supranational institutions, especially the EU legislator and the ECJ, for administering the demoicratic interdependence of the EU peoples. Demoicracy thus understood focuses on the EU peoples as human collectives at the heart of the EU polity, which helps to translate the above State theories that emphasize popular self-determination to the EU level.

A demoicratic justification is not only attractive because it helps to conceptualize territorial claims in a supranational political community composed of sovereign Member States. Demoicracy is itself characterized by the reflexive relationship between autonomous national demos and interdependent demoi, which lies at the heart of the territorial claims analyzed in this Article. Take the brief discussion above in relation to the obligation to protect the Member States' territorial integrity in Article 4(2) TEU to show that the EU's territorial claims ought to be compatible with the legitimate territorial claims of its Member States. A demoicratic justification is also well-apt to evaluate the jurisprudence discussed in the introduction that sparked the present reflections. The suggestion of the Court in Slovenia/Croatia that it is the Member States' legal duty under Article 4(3) TEU to "strive sincerely to bring about a definitive legal solution ... . and to bring their dispute to an end by using one or other means of settling it" 129 does not sound like an outrageous transgression of competences, but as inspired by the cooperation of peoples that underwrite the EU territory. The ECJ's recent interpretation of the GDPR to require third countries to ensure "essentially equivalent" data protection can similarly be motivated by the aim to guarantee the consistent and high level of protection of personal data throughout the EU. ${ }^{130}$ The ECJ thus protects the legal regime the Europeans have given themselves in demoicratic deliberations in the EU legislative process that resulted in the GDPR. These examples illustrate both why

\footnotetext{
${ }^{126}$ For an elaboration of this Rawlsian idea, see Stephen Macedo, What Self-Governing Peoples Owe to One Another: Universalism, Diversity, and the Law of Peoples, 72 Fordham L. Rev. 1721, 1729 (2004).

${ }^{127}$ Richard Bellamy, A Republican Europe of States: Cosmopolitanism, Intergovernmentalism and Democracy IN THE EU 11 (2019).

${ }^{128}$ Id. at ch. 6 .

${ }^{129}$ Slovenia, Case C-457/18 at para. 109.

${ }^{130}$ See Data Prot. Comm'r, Case C-311/18 at paras. 101, 105.
} 
we need a theory to evaluate the legitimacy of the EU's territorial claims and why demoicracy is a good starting point. The full development of such a theory, however, must wait for another day.

\section{Conclusion}

In the writings of important thinkers from Aeschylus over Pope Pius II to Montesquieu, Europeboth as a place and an idea-has historically been defined by what it excludes as much as by what it includes. ${ }^{131}$ To my mind, the EU inherits and institutionalizes this historical legacy, which its various territorial claims make explicit.

The EU joins individual national territories together to form a bounded EU territory. ${ }^{132}$ It does not imitate statist territoriality. That is, it does not claim ultimate authority over a distinct chunk of the earth. ${ }^{133}$ Instead, the EU's leitmotif is to open national territories and to create a transnational, mutually integrating, and yet bounded space. It de-territorializes national rule to a considerable extent and re-territorializes a different version of territorial rule on the EU level. In sum, territoriality - as a distinctly supranational normative relationship between peoples, place, and power-forms part of the EU's authority claim. Succinctly: "The territoriality of the European Union is much different from that of the modern States, but European integration is certainly not the end of territoriality." ${ }^{34}$

While this Article briefly explored the idea of demoicracy in this regard, we still lack a convincing theory that provides a moral standard to legitimize and evaluate the EU's notion of territorial rule. Especially considering the recent jurisprudence, which, as a result, must walk on this theoretically untrodden path, it is about time we develop one.

Josef Weinzierl is a DPhil (PhD) candidate at the University of Oxford (Faculty of Law).

\footnotetext{
${ }^{131}$ See the excellent collection of writings on the idea of Europe in Peter Burke, Did Europe Exist Before 1700?, 1 HIST. EUR. IDEAS 21 (1980).

${ }^{132}$ See Hassner, supra note 43, at 34; Mamadouh \& Dijkink, supra note 44, at 151.

${ }^{133}$ See Bialasiewicz, Elden \& Painter, supra note 15, at 346.

${ }^{134}$ Mamadouh, supra note 24, at 433. See also Burgess, supra note 27.
}

Cite this article: Weinzierl J (2021). Territoriality Beyond the State: The EU's Territorial Claims and the Search for Their Legitimacy. German Law Journal 22, 650-672. https://doi.org/10.1017/glj.2021.24 